\title{
Phytoremediation of Heavy Metals Spiked Soil by Polyscias fruticose
}

\author{
NASEER INUWA DURUMIN IYA ${ }^{1,2 *}$, ZAINI BIN ASSIM¹, ISA BIN IPOR ${ }^{1}$, \\ SAMINU MURTALA YAKASAI ${ }^{2}$, SHINA ISMAIL SADIQ ${ }^{2}$ and BINTA HADI JUME ${ }^{3}$
}

\author{
${ }^{1}$ Faculty of Resource Science and Technology, Universiti Malaysia, \\ 94300 Kota Samarahan, Sarawak, Malaysia. \\ ${ }^{2}$ Department of Chemistry, Federal University Dutse, Ibrahim Aliyu Bye-Pass, \\ 7156 - Dutse, Jigawa State, Nigeria. \\ ${ }^{3}$ Department of Chemistry, Preparatory School, Aljoup University, Sakaka, \\ 72388, Aljoup Region, KSA. \\ ${ }^{*}$ Corresponding author E-mail: nasduruminiya@yahoo.com
}

http://dx.doi.org/10.13005/ojc/350135

(Received: November 24, 2018; Accepted: January 10, 2019)

\begin{abstract}
This study was to assess the phytoremediation potential of Polyscias fruticose in the removal of heavy metals from spiked soil. P. fruticose cuttings were transplanted then grown on $2.00 \mathrm{~kg}$ soil spiked with several heavy metals in polyethylene bags. The experiment was conducted for 300 days and concentrations of heavy metals in plant and soil over the growth period were determined. Appreciable concentrations of heavy metals in $P$. fruticose parts were obtained. The indices used to show the ease of heavy metals uptake and translocation indicated that $\mathrm{Co}, \mathrm{Cr}, \mathrm{Mn}, \mathrm{Ni}$ and $\mathrm{Pb}$ displayed the greatest ease of absorption while $\mathrm{Zn}$, Fe and Cu were accumulated in the root but not translocated to the shoot. The results obtained shows that this study pioneered the use of $P$. fruticose in the phytoremediation of several heavy metals spiked soil at a greenhouse level.
\end{abstract}

Keywords: Heavy metal, Phytoremediation, Polyscias fruticose, Phytoextraction, Spike, Bio-concentration factor.

\section{INTRODUCTION}

The world industrial activities, such as electroplating, fertilizer, municipal solid waste, smelting, gas exhaust, pesticides, fuel production, iron ores, energy production and mining have a large contribution in the release of significant amounts of toxic compounds into the biosphere, among which are trace heavy metals ${ }^{1}$. Human activities, urbanization and industrial development discharge harmful wastes into the environment, such as soil, water and air. These harmful wastes are classified as contaminants, and their outcomes are harmful and toxic to the soil, water, air, human, animals,

This is an Open Access article licensed under a Creative Commons license: Attribution 4.0 International (CC- BY). Published by Oriental Scientific Publishing Company @ 2018

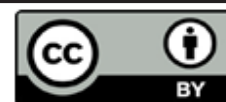


plants and microorganism. Common harmful heavy metals are $\mathrm{Al}, \mathrm{Cr}, \mathrm{Cd}, \mathrm{Cu}, \mathrm{Pb}, \mathrm{Mn}, \mathrm{Zn}, \mathrm{Hg}$ and some metalloids like $\mathrm{Sb}$ and $\mathrm{As}$ are also harmful ${ }^{2}$. Heavy metals are dangerous to terrestrial and aquatic ecological community, and affect the health of human and animal ${ }^{3}$. They get in contact with human and animal body system through food chain, water, atmospheric air and also direct or indirect contact with the skin'2. The major health problem related to consumption or coming in contact with heavy metals are cardiovascular disease, prolonged anaemia, cognitive disability ${ }^{4}$, cancer problem, kidneys diseases ${ }^{5}$, problem of nervous system and brain damage, skin infection, bones and teeth ${ }^{2}$. Reducing harmful heavy metals from the environment is necessary and very important in order to prevent the environment from the harmful effects of heavy metals and also save it for future uses. Many physical, chemical and biological techniques have been applied for the removal and reduction of heavy metals, which is considered to be cost effective and more complex ${ }^{1}$. The use of plant to reduce or remove harmful contaminants from polluted environment is defined as biological remediation ${ }^{6}$. Biological remediation is considered to be the most efficient method of heavy metal reduction or removal. The techniques include land forming, bioremediation, bioventing, bioleaching, bioreactors, bio-remediation composting, phytoremediation, bio-augmentation and bio-stimulation. Among these techniques, bioremediation and phytoremediation are the most important methods ${ }^{6}$. These techniques have more advantages over physical and chemical techniques because it is a natural process, environmentally friendly, less expensive, no machine application and publically accepted. It also preserve natural soil properties and depend on solar energy ${ }^{6}$. Therefore, the aim and objectives of this study were (a) to assess the ability of $P$. fruticose to survive and grow on a soil spiked with several heavy metals (b) and to evaluate the uptake and translocation of heavy metals to aboveground tissues. The novelty of the present study is the potential of $P$. fruticose to grow in a heavy metals contaminated soil, extract, accumulate and translocate heavy metals to above ground tissues in a normal plant growth condition at the greenhouse. The outcome of the experiment shows that $P$. fruticose was effective and efficient for the phytoremediation of soil spiked with several heavy metals.

\section{MATERIALS AND METHODS}

The study was performed at the greenhouse of Faculty of Resource Science and Technology, Universiti Malaysia Sarawak, (N 010 33' 03.6" E $\left.110045^{\prime} 56.5^{\prime \prime}\right)$ from $17^{\text {th }}$ April 2017 to $26^{\text {th }}$ March, 2018. The harvest of the first set of $P$. fruticose after 2 months took place on 20th Jun, 2017.

\section{Apparatus and Instrumentations used}

Perkin Elmer Atomic Absorption Spectrometer (AAS) model Optima 8300 series, Stuart/FX105-27 series muffle furnace, Memmert oven model XMM-UNB200, stainless steel mesh BS 410-1: 2000 model, Favorit HS 0707V2 series hot plate, polyethylene bag, weighing balance model FX-300i series 15621105 and scoop.

\section{Soil and Plant Samples}

In this study Polyscias fruticose (Ming Aralia) plant was selected for its ability to produce good root system and more biomass. It is from the family of Araliaceae, Polyscias is the genus and fruticose is its species. Fresh young plant samples of $P$. fruticose were collected within the Universiti campus and about $5.0 \mathrm{~cm}$ cuttings were made and kept for $3 \mathrm{~h}$ to dry. About $2.5 \mathrm{~cm}$ from the bottom of the cutting were scraped (one side) with a sterilized surgical blade to enable the growth of roots. These cuttings were used for pot experiment. The top soil was collected from Kota Samarahan, Kuching, it was allowed to dry and larger particles were removed and homogenized.

\section{Pot Experiment}

Greenhouse experiment was conducted according to the procedure described in ${ }^{8}$ with minor modification. Poly bags were filled with $2.0 \mathrm{~kg}$ soil spiked with a $50 \mathrm{mg} / \mathrm{kg}$ solution containing a mixture of several heavy metals at a greenhouse. Six (6) sets of cuttings each contain five $(n=5)$ replicates which include control were set as required in a growth archaic. The greenhouse growth conditions were $9 \mathrm{~h}$ dark at $19^{\circ} \mathrm{C}$ and $24^{\circ} \mathrm{C}$ for $15 \mathrm{~h}$ daylight. The plants were watered every other day and were netted. Plants were gathered from poly bags and washed with distilled water after every 2 months for the period of 10 months. The plants were separated into root, stem and leaf then dried in an oven for 3 days at $65^{\circ} \mathrm{C}$. 


\section{Quality control and quality assurance}

Plastic containers and glasswares used in the experiment were washed with tap water and distilled water then immersed in $2.0 \mathrm{~N} \mathrm{HNO}_{3}$ solutions before use. All the standard reagents and chemicals used for atomic absorption spectrophotometer (AAS) analysis were of analytical grade and certified standards. Five replicates samples data of analysis showed a good precision within the results.

\section{Soil and Plant analyses Soil analyses}

Soil sample was grind and sieved through $2.0 \mathrm{~mm}$ stainless steel mesh model BS 410-1:2000 before the analysis. The experiment was carried out as stated in the procedure outlined by Durumin lya et al., ${ }^{9}$ with minor modifications. Exactly $1.0 \mathrm{~g}$ of dried soil sample in a crucible was dry-digested (dry ashing) by heating to ash at $500^{\circ} \mathrm{C}$ for $5.0 \mathrm{~h}$ in a Stuart/FX105-27 series muffle furnace. On cooling, $1.0 \mathrm{~mL}$ of distilled water and $1.0 \mathrm{~mL}$ of concentrated $\mathrm{HNO}_{3}$ acid were added. It was evaporated to dryness on a Favorit HS 0707V2 series hot plate then heated to $400^{\circ} \mathrm{C}$ for $15 \mathrm{~min}$ in a muffle furnace. Immediately $1.0 \mathrm{~mL}$ and $2.0 \mathrm{~mL}$ of distilled water and concentrated $\mathrm{HCl}$ acid, respectively were added then evaporated to dryness. Then $10.0 \mathrm{~mL}$ of distilled water was added and filtered with 0.45 micron filiter in $100 \mathrm{~mL}$ volumetric flask. Distilled water was added to the mark of $100 \mathrm{~mL}$ volumetric flask.

\section{Plant organs analyses}

Plant organs analysis was performed as stated in the procedure decribed by Durumin lya et al., ${ }^{9}$. Plant organs were grind to fine powder and digested before heavy metals analysis. Approximately, $0.5 \mathrm{~g}$ of each plant organ (root, stem and leaf) was ashed at $480^{\circ} \mathrm{C}$ for $4.0 \mathrm{~h}$ in a muffle furnace model Stuart/FX105-27 series. At a low temperature exactly $1.0 \mathrm{~mL}$ of distilled water and $1.0 \mathrm{~mL}$ of concentrated $\mathrm{HNO}_{3}$ acid were added. It was then evaporated to dryness on a hot plate model Favorit HS 0707V2 series. When cooled, $2.0 \mathrm{~mL}$ of $20 \%(\mathrm{v} / \mathrm{v}) \mathrm{HNO}_{3}$ was added then heated to $100^{\circ} \mathrm{C}$ on hot plate. Then $20 \mathrm{~mL}$ of distilled water was added to sample and filtered through $0.45 \mu \mathrm{m}$ filter paper into $100 \mathrm{~mL}$ volumetric flask distilled water was then added to $100 \mathrm{~mL}$ mark of the flask. Soil and plants samples were analyzed on a Perkin Elmer AAS model Optima 8300 series.

\section{Phytoextraction and phytostabilization potential of the plant}

Bioconcentration factor $(B C F=$ Metal concentration in tissue of whole plant/Initial concentration of metal in soil) and translocation factor (TF = Shoot metal accumulation/ Root metal accumulation) were the two indices used to calculate the potential of $P$. fruticose to be a phytoextractor of the heavy metals or phytostabilizer ${ }^{10,11}$. Plants are suitable for phytoextraction if they have high BCF values greater than 1, and suitable for phytostabilization if BCF value is high and TF value is low ${ }^{10}$.

\section{Statistical analysis}

All data reported were averaged values, standard deviation (SD) and standard error of five good replicates selected from eight independent replicates. Statistical analysis of the data was carried out using one-way analysis of variance (ANOVA). Differences in the concentration between harvesting time and between plant organs were considered statistically significant value at p 0.05. Capital letters were used to indicate the differences in soil and plant organs, while small letters were used to indicate the differences of heavy metals concentration on different harvesting period. The statistical analysis was accomplished by IBM SPSS Statistics version ${ }^{24}$.

\section{RESULTS AND DISCUSSION}

\section{Plant growth}

$P$. fruticose survived in the soil spiked with several heavy metals. Plant growth was observed to be around $98 \%$ and plant was able to adapt the condition of the soil. Moreover, it was observed that the $P$. fruticose survive and grow without any adverse effect or sign of yellowish leaf or undeveloped growth throughout the period. P. fruticose has the potential to uptake 8 heavy metals during first harvest in its roots, these are $\mathrm{Co}, \mathrm{Cr}, \mathrm{Cu}, \mathrm{Pb}, \mathrm{Fe}, \mathrm{Mn}, \mathrm{Ni}$ and $\mathrm{Zn}$ and were able to translocate some of the heavy metals to the aboveground biomass. Cadmium and arsenic were not detected by the plant, while the accumulation of Fe was higher compared to other metals.

\section{Heavy Metals uptake by the plant organs}

The uptake of heavy metals (Co, $\mathrm{Cr}, \mathrm{Cu}$, $\mathrm{Ni}, \mathrm{Fe}, \mathrm{Zn}, \mathrm{Mn}$, and $\mathrm{Pb}$ ) in the root, stem and leaf tissues of $P$. fruticose was investigated. A significant $(p<0.05)$ quantities of heavy metals were observed in the root more than the stem and leaf except for 
Co and $\mathrm{Cr}$ which both were accumulated more in the leaf on 120 harvesting day. However, the quantity of Fe were consistently more in soil than in the root, stem and leaf of the plant on all the harvesting days. In this experiment, heavy metals uptake by the roots were in the ranges of (36.88 to 384.19$) \mathrm{Cu},(1.99$ to 9.24$)$ Co, (12.61 to 68.94$) \mathrm{Cr}$, (24.41 to 226.36) Mn, (21.01 to 56.89$) \mathrm{Ni},(14.56$ to 193.34$) \mathrm{Zn},(3.09$ to 21.75$)$ $\mathrm{Pb}$ and (23.14 to 499.24) Fe, all in mg/kg. Moreover, the accumulation of heavy metals in the plant organs was higher higher than its concentration in the control plant organs.

\section{Cobalt}

$P$. fruticose was able to uptake and accumulates Co from heavy metals spiked soil with a high concentration. As it was shown in Fig. 1, a significant $(p<0.05)$ concentration of Co in the leaf of the plant was observed to be $15.0 \pm 6.23 \mathrm{mg} / \mathrm{kg}$ on 120 harvesting day, followed by the root on 120 and 240 harvesting days with concentration 7.588 $\pm 0.43 \mathrm{mg} / \mathrm{kg}$ and $9.24 \pm 0.85 \mathrm{mg} / \mathrm{kg}$ respectively. It was observed that the concentration of $\mathrm{Co}$ in soil and plant organs on 300 days were lower than those on 240 days. The concentration of Co accumulated by plant organs was 1 to several folds compared to control soil and plant. Another high accumulation was observed in the stem of the plant on 240 day with concentration $6.77 \pm 1.22 \mathrm{mg} / \mathrm{kg}$. In a similar study on $\mathrm{Co}, \mathrm{Cr}$ and $\mathrm{Ni}$ contents in soils and plants from a Serpentinite quarry, the roots of Juncus sp. accumulated a large amount of Co, both Festuca rubra L. and Juncus sp. L. accumulated $\mathrm{Co}$ in the roots more than the shoot ${ }^{12}$, while in contrary to this study the accumulation was not consistent. Accordingly, concentration of Co was found in the tissues of Luff cylindrica planted on two different soil samples (i) and (ii) with values 0.414 and $0.597 \mathrm{mg} /$ $\mathrm{kg}$, respectively ${ }^{13}$. Clethra barbinervis was found to accumulate quiet a number of heavy metals such as $\mathrm{Mn}, \mathrm{Co}, \mathrm{Zn}, \mathrm{Ni}$ and $\mathrm{Cd}$ but accumulated more $\mathrm{Co}$ and $\mathrm{Ni}$ in the leaf ${ }^{14}$. It was observed that $\mathrm{Ni}$ and Co interacts regularly and acts against each other in the plant ${ }^{15}$. Another opposite interaction between $\mathrm{Co}$ and $\mathrm{Ni}$ was recorded from Alyssum bertolonii and Berkheya coddii and this opposite relationship between $\mathrm{Co}$ and $\mathrm{Ni}$ may lead to great competition in their translocation, binding ligands and also their function ${ }^{14}$. The endurance and accumulation mechanism of Co are not sufficiently understood which could be due to some Co accumulator plants use to uptake and accumulate $\mathrm{Cu}^{14,16}$. It was reported that a common criteria used to identify a metal hyper-accumulator plant followed the concentration of metal in dried leaf of a plant that grow in a natural way. A hyper-accumulator plant for $\mathrm{Co}, \mathrm{Cu}$ and $\mathrm{Cr}$ should accumulate $300 \mathrm{mg} / \mathrm{kg}$ of the metal before being considered as hyper-accumulator ${ }^{16}$. Another important issue about $\mathrm{Co}$ accumulator is considered to be Co ddetoxification will shun the uptake of ions that can cause stress from oxidation ${ }^{17}$.

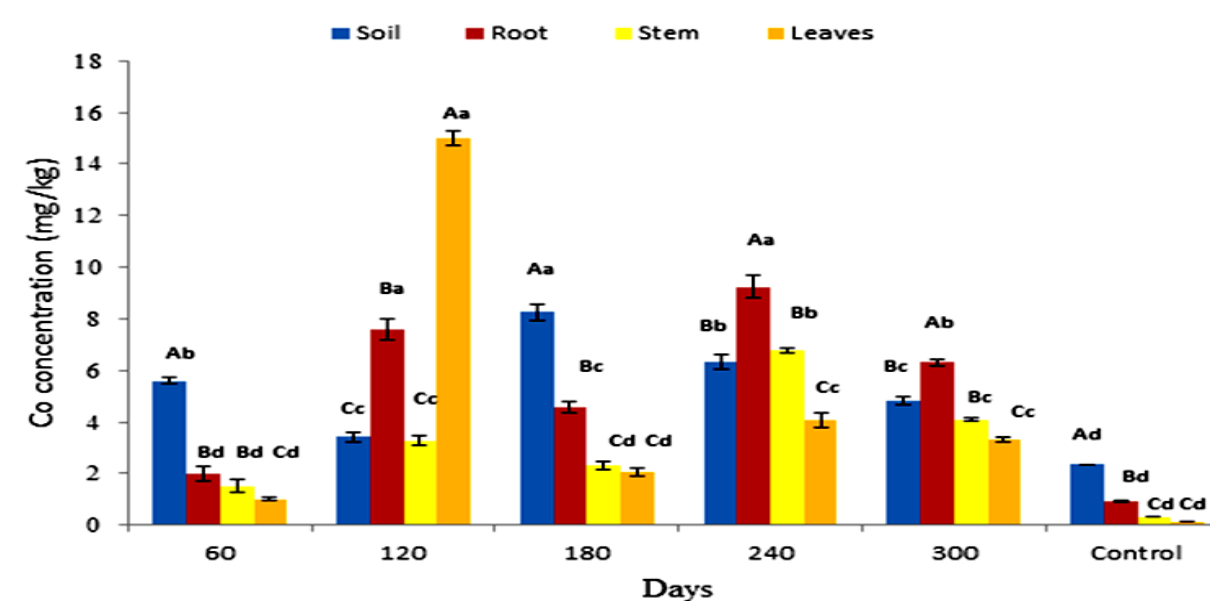

Fig. 1. Accumulation of Co concentration in soil and $P$. fruticose root, stem and leaf on all the harvesting days

\section{Chromium}

Uptake of chromium by $P$. fruticose grown on a soil contaminated with heavy metals is shown on
Fig. 2. The amount of $\mathrm{Cr}$ in $P$. fruticose was observed to be significant $(p<0.05)$ in the root, stem and leaf on 120 harvesting day. Furthermore, high accumulation 
was observed from the plant leaf on 120 harvesting day with an amount $98.74 \pm 11.97 \mathrm{mg} / \mathrm{kg}$. Other high $\mathrm{Cr}$ accumulations were also recorded on the soil, root and stem on 120 harvesting days with a concentration of $50.65 \pm 2.87,68.94 \pm 9.97$ and 89.74 $\pm 12.14 \mathrm{mg} / \mathrm{kg}$ respectively. It was observed that the accumulation of $\mathrm{Cr}$ on 300 harvesting days was lower compared to 240 days accumulation. Accordingly, $\mathrm{Cr}$ concentrations in control soil and control plant part were several folds lower than the treated ones. This experiment agrees with a similar study conducted on soil and plants from Serpentinite quarry, it was observed that, the two plants Festuca rubra L. and Juscus species L. were able to accumulate $\mathrm{Cr}$ in their roots and shoots. The concentration of $\mathrm{Cr}$ accumulated by F. rubra and Juscus species were ranged $13.74 \pm 0.63$ to $15.37 \pm 1.60,11.21 \pm 1.02$ to $46.83 \pm 5.91 \mathrm{mg} / \mathrm{kg}$, respectively ${ }^{12}$. It was noticed that $\mathrm{Cr}$ accumulation was significantly higher in the roots than in the shoot. It was also reported that Jatropha curcas accumulated $\mathrm{Cr}$ in the root more than stem and leaf with concentration $27.99 \pm 8.10,15.90 \pm 4.52$ and $15.17 \pm 3.31 \mathrm{mg} / \mathrm{kg}$, respectively ${ }^{1}$.

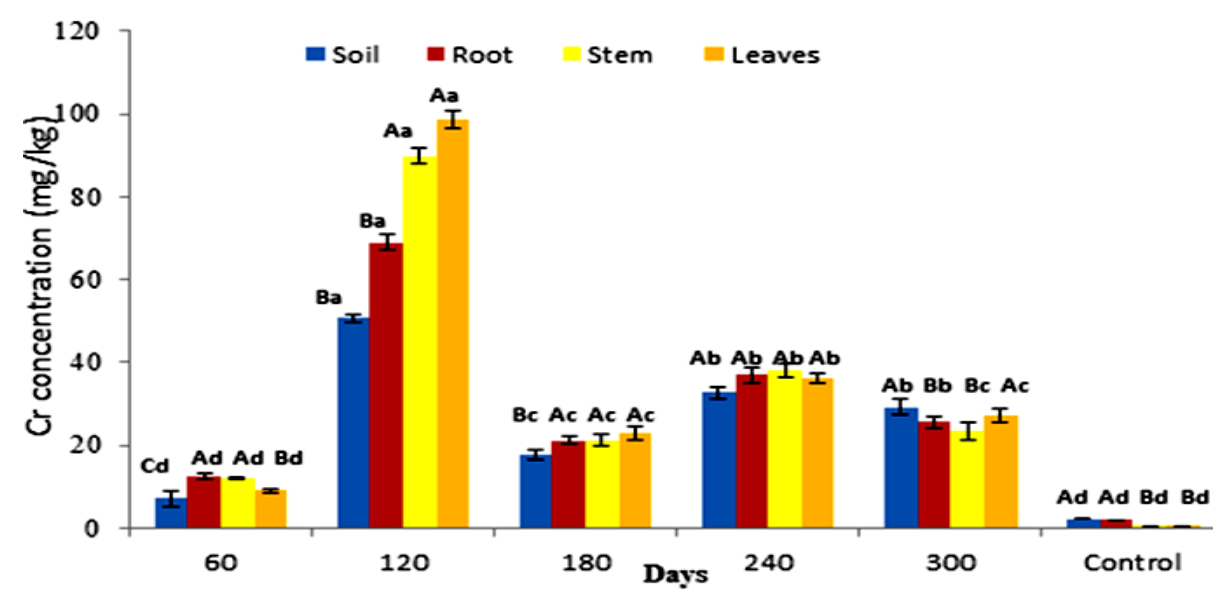

Fig. 2. Accumulation of $\mathrm{Cr}$ concentration in soil and $P$. fruticose root, stem and leaf on all the harvesting days

These results agree with findings of Adki et al., ${ }^{18}$ and Rafati et al., ${ }^{19}$, where both authors found out that $\mathrm{Cr}$ concentration is lower at the shoot and vegetables of the plant compared to the root. In another study which is contrary to this one, Portulaca oleracea has the potential of accumulate higher concentration of $\mathrm{Cr}>1000$ $\mathrm{mg} / \mathrm{kg}^{20}$, and a suggestion was made that any plant that can accumulate $\mathrm{Cr}$ more than 1000 $\mathrm{mg} / \mathrm{kg}$ should be considered as a Cr hyperaccumulator plant ${ }^{21}$. The antagonistic relationship and synergistic interactions between the concentration of $\mathrm{Cr}$ and other heavy metals in plants tissues were observed ${ }^{22}$. It was reported that $\mathrm{Cr}$ use to interact with the uptake of other heavy metals such as $\mathrm{Fe}$ and $\mathrm{Mn}$ in the root and aboveground which eventually reduces organs or tissue concentration ${ }^{22}$. In this study, $P$. fruticose grown on soil spiked with several heavy metals was found to accumulate a significant $(p<0.05)$ quantity $98.74 \mathrm{mg} / \mathrm{kg}$ of $\mathrm{Cr}$ dry weight in the leaf. Based on the $\mathrm{Cr}$ uptake in this study, $P$. fruticose cannot be considered as $\mathrm{Cr}$ hyper accumulator plant. It was observed that some plants grown on soil treated with wastewater containing $\mathrm{Cr}$, less quantity was transferred to the aboveground plant organs. Moreover, plants grown on hydrated magnesium silicate soil rich in $\mathrm{Cr}$ were found to accumulate few quantities. Generally, plants differ from their potential to absorb and retain $\mathrm{Cr}$ in organs and most plants have low capability to uptake and transfer $\mathrm{Cr}$ to aboveground tissues ${ }^{9}$.

\section{Copper}

A significant $(\mathrm{p}<0.05)$ value of $\mathrm{Cu}$ was observed in the root of $P$. fruticose plant (384.19 \pm $70.69 \mathrm{mg} / \mathrm{kg}$ ) on 180 harvesting days as presented in Fig. 3. Other high accumulations were found in the root $42.62 \pm 0.55,36.88 \pm 0.96,69.58 \pm 0.85$ and $73.18 \pm 1.03 \mathrm{mg} / \mathrm{kg}$ on $60,180,240$ and 300 harvesting days respectively. The accumulation of $\mathrm{Cu}$ by this plant was observed to be high in the root on all harvesting days. Without considering the harvesting days, all accumulations in the stem and leaf of the plant were far below the concentration in the root. 


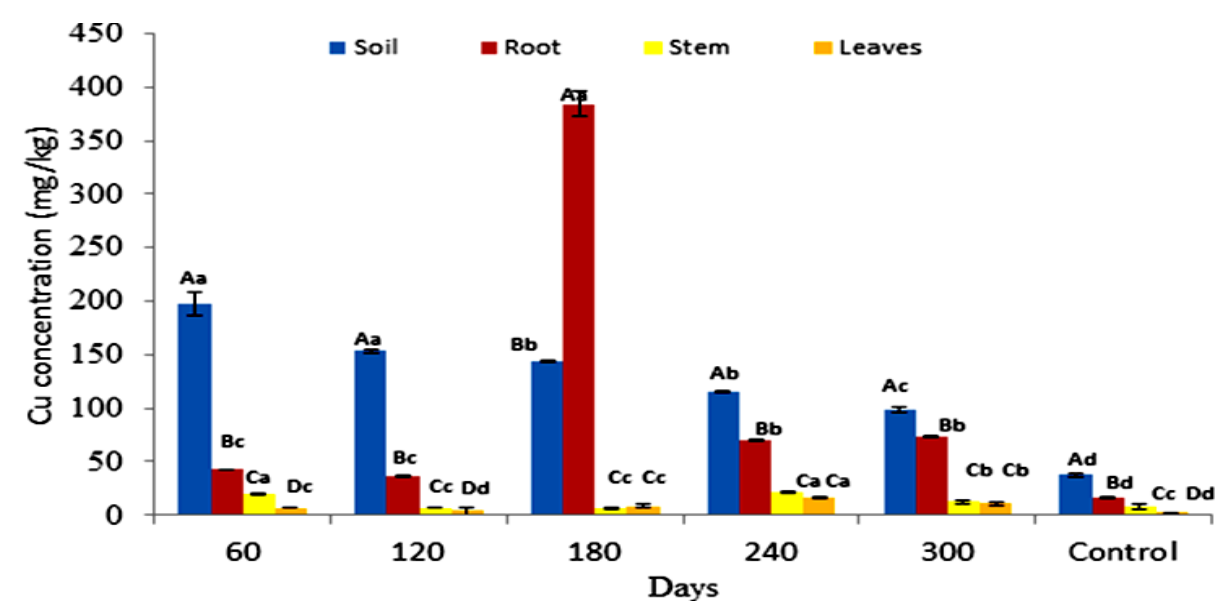

Fig. 3. Accumulation of $\mathrm{Cu}$ concentration in soil and $P$. fruticose root, stem and leaf on all the harvesting days

It was observed in a similar case, where both Brassica napus and Brassica juncea accumulated more $\mathrm{Cu}$ in their roots than in shoots under Cu stress for 7 and 14 days in hydroponic solution ${ }^{23}$. In contrast, the study carried out on the use of Amaranthus paniculatus and $B$. juncea for phytoextraction of $\mathrm{Pb}$ and $\mathrm{Cu}$ from contaminated soil, both plants were able to accumulate $\mathrm{Cu}$ concentration ranged from 15.7 to 18.1 and 18.7 to $21.4 \mathrm{mg} / \mathrm{kg}$ respectively. But the concentrations were found to be 2 to 4 times more in the shoots than in the roots of the plants ${ }^{24}$. Cu is a metal that plants needs for growth, but a concentration of Cu beyond $20.00 \mathrm{mg} / \mathrm{kg}$ in the aboveground organs is harmful to the plant ${ }^{9}$. In this experiment, $\mathrm{Cu}$ accumulation was higher ( $p$ 0.05) in roots $384.19 \pm 20.69 \mathrm{mg} / \mathrm{kg}$ than stem $21.87 \pm 0.67$ $\mathrm{mg} / \mathrm{kg}$ and leaf $16.39 \pm 0.98 \mathrm{mg} / \mathrm{kg}$. Higher quantity of $\mathrm{Cu}$ in the roots may be due to its ability to move from soil to roots continuously which make it easier for $P$. fruticose to absorb more and translocate less to above ground tissue. Deficient transfer of heavy metals to aboveground plant organs could be to the retention of heavy metals in protoplasmic fractions of vacuoles, producing coordination complex with some organic acids at the two layers of root or due to separation of heavy metals from anionic sites of cell wall ${ }^{25}$.

Iron

A significant $(p<0.05)$ concentration of $\mathrm{Fe}$ was observed in P. fruticose root on 120 harvesting day with values $499.24 \pm 29.69 \mathrm{mg} / \mathrm{kg}$ as it was shown in Fig. 4. Other high amount of $\mathrm{Fe}$ was found in the stem and leaf on 180 harvesting day with concentration of $382.51 \pm 106.71$ and 433.08 $\pm 199.08 \mathrm{mg} / \mathrm{kg}$ respectively. Moreover, significant $(p<0.05)$ concentration of Fe in plant parts was ranged 7.13 to $499.24 \mathrm{mg} / \mathrm{kg}$. Increases of Fe uptake by the root from 60 to 300 harvesting days were also observed with concentration ranged 23.14 to 499.24 $\mathrm{mg} / \mathrm{kg}$. All the quantity of $\mathrm{Fe}$ accumulated in the $P$. fruticose organs was higher than the control soil and plant parts. This experiment agreed with the study carried out on Camphorosma monospeliacum and Salsola soda for the accumulation of $\mathrm{Pb}, \mathrm{Fe}, \mathrm{Mn}, \mathrm{Cu}$, and $\mathrm{Zn}$ in industrial town of Vian. It was reported that the amount of Fe accumulated by the roots of the two plants has a significant difference at the contaminated area with a concentrations ranged 349.6 to 22645.3 $\mathrm{mg} / \mathrm{kg}$ and 309.6 to $10604.9 \mathrm{mg} / \mathrm{kg}$ for root and shoot, respectively, with a maximum concentration in the roots of $S$. soda and highest amount in shoots of C. monospeliacum ${ }^{26}$. In another study conducted on Salvinia cucullata treated with different level of paper mill effluent, the plant accumulated $\mathrm{Fe}$ $(14,969 \pm 1689 \mathrm{mg} / \mathrm{kg})$ in the root and $13,379 \pm 1206$ $\mathrm{mg} / \mathrm{kg}$ in the leaf and both were several folds greater than the control ${ }^{27}$. In this study, the toxic effect of $\mathrm{Cr}$ was not observed, however, a significant quantity of Fe in the tissues of $P$. fruticose was observed. There are several factors which increase the performance of the plant in removing Fe from contaminated soil such as the root zone, species of the plant, physical and chemical properties of soil medium, chelating agent addition, environmental condition and the bioavailability of metal ${ }^{28}$. Accordingly, a significant reduction $(p<0.05)$ of $\mathrm{Fe}$ quantity in the spiked soil and an increase in $\mathrm{Fe}$ accumulations into the plant organs was observed. This indicates that $P$. fruticose 
was able to tolerate, uptake and accumulate higher concentrations of Fe from spiked soil medium. Furthermore, plants uptake $\mathrm{Fe}$ in the form of ferric $\left(\mathrm{Fe}^{3+}\right)$ ions and ferrous $\left(\mathrm{Fe}^{2+}\right)$ ions and make effective use of different Fe absorption mechanisms. The mechanism of some plant in Fe uptake includes the release of proton $\left(\mathrm{H}^{+}\right)$and gets reduced by the root of the plant in order to lower the soil $\mathrm{pH}$ value. And low $\mathrm{pH}$ value at the root zone increases and improves Fe solubility and uptake, respectively ${ }^{29}$.
Moreover, the metals use to pass through the roots before translocation to the aboveground organs of the plant. Plant roots system play an important role in nutrients and water uptake by osmosis from the soil. High quantity of Fe uptake through osmosis was transferred to aerial plant organs via xylem ${ }^{29}$. And also Fe was translocated via phloem vessels due to some insufficient transpiration flow of xylem vessels in some young plant organs such as apex ${ }^{29}$.

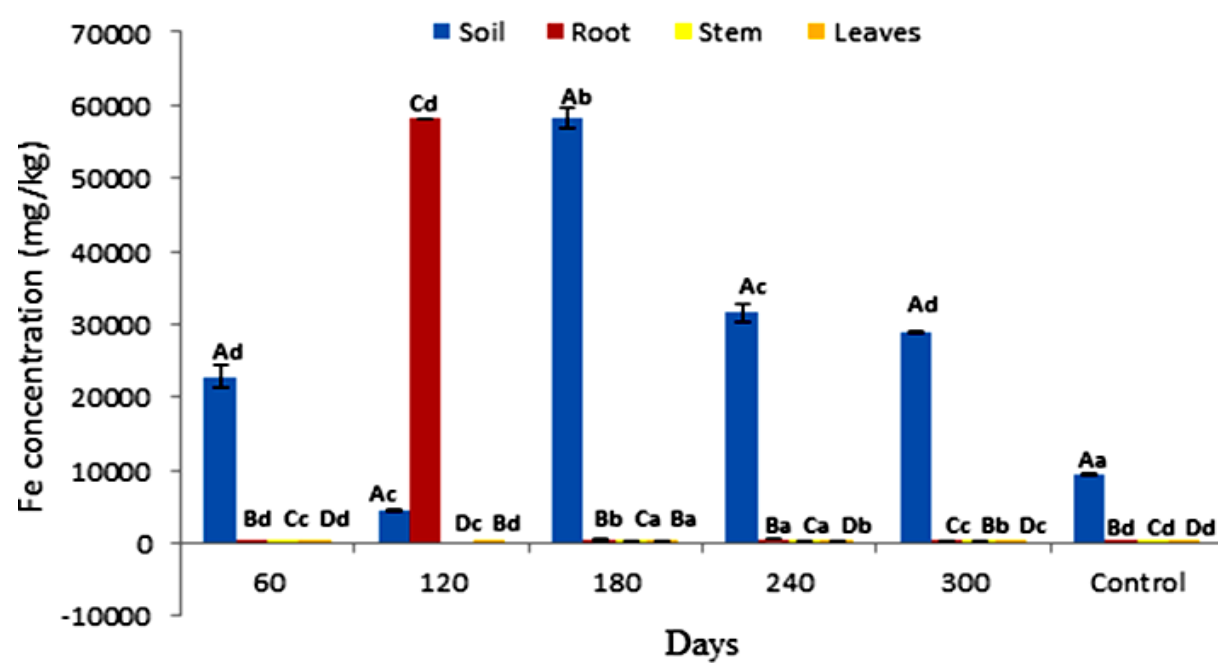

Fig. 4. Accumulation of Fe concentration in soil and P. fruticose root, stem and leaf on all the harvesting days

\section{Manganese}

Accumulation of $\mathrm{Mn}$ by $P$. fruticose on the experimental days was presented on Fig. 5 . The plant has the potential to absorb a significant $(p<0.05)$ concentration of $\mathrm{Mn}$ from contaminated soil to the root and translocated it to the shoot. A high accumulation was observed in the root on all the harvesting days with a value of $24.42,101.65$, 226.36, 98.68 and $109.97 \mathrm{mg} / \mathrm{kg}$ on 60,120 , 180,240 and 300 experimental days respectively. Furthermore, the amount of $\mathrm{Mn}$ accumulated by the plant tissues increases in the trend stem > leaf $>$ roots. The concentrations of $\mathrm{Mn}$ accumulated by $P$. fruticose parts were were higher than the control plant with several folds. This experiment agreed with the study conducted on Eucalyptus grandis and $E$. urophylla to identify a Mn hyper-accumulator. Both plants were subjected to the same treatment of hydroponic solution 5.0, 500, 10000 and 20 $000 \mu \mathrm{M}$ of $\mathrm{Mn}$ and were able to accumulate higher concentration in the leaf and stem on the first 3 treatment. On exposure to higher hydroponic solution, a much higher accumulation of $\mathrm{Mn}$ was observed in the stem of the plant with concentrations $52,540 \mathrm{mg} / \mathrm{kg}$ compared to the leaf and $\operatorname{root}^{30}$. However, the accumulation of $\mathrm{Mn}$ in the stem of the plant at an early stage may be due to the important way of action to prevent the young plant from $\mathrm{Mn}$ stress $^{30}$. This study is contrary to the experiment conducted by Satpathy and Reddy ${ }^{31}$, in which they showed that accumulation of Mn by $B$. juncea, was higher in stem more than the leaf and root. The ranges of Mn accumulated by the plant tissues were 46.0 to $2041.5,57.0$ to 3781.0 and 50.1 to 3260.8 $\mathrm{mg} / \mathrm{kg}$ in root stem and leaf, respectively under the same treatment. The amount of $\mathrm{Mn}$ accumulated by $B$. juncea increases in the trend roots $>$ stem $>$ leaf. Moreover, an explanation was made that the quantity of $\mathrm{Mn}$ accumulated in the aboveground tissues of Mn hyper-accumulator plant is always higher than in the root which shows that the plant has potential to uptake, translocate and keep $\mathrm{Mn}$ in the aboveground tissues ${ }^{9}$. 


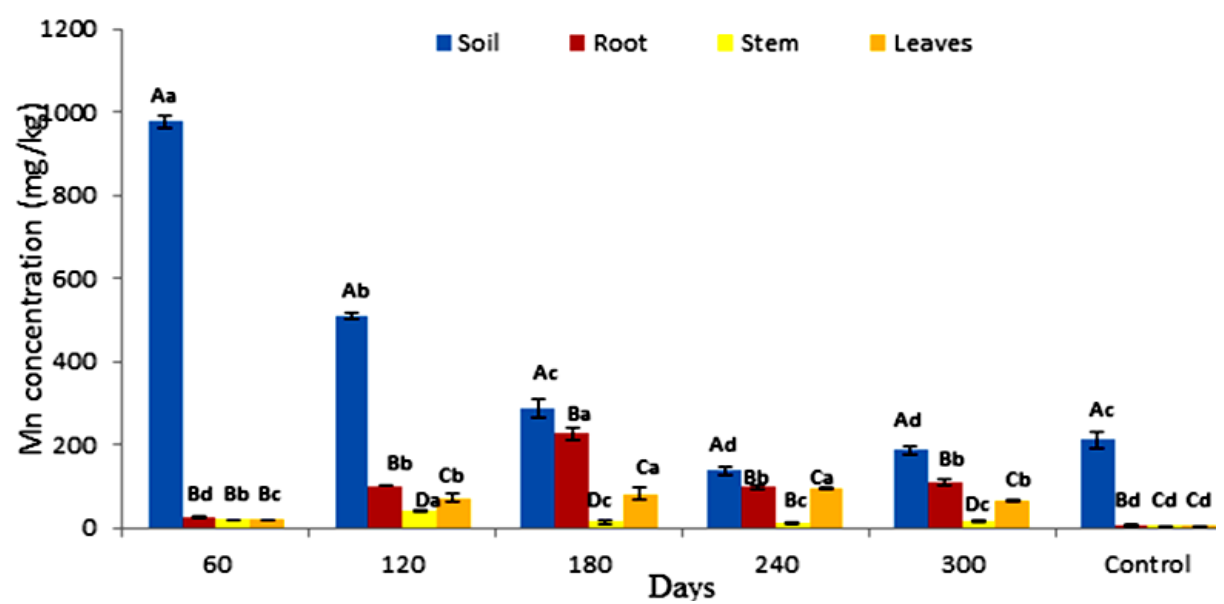

Fig. 5. Accumulation of $\mathrm{Mn}$ concentration in soil and $P$. fruticose root, stem and leaf on all the harvesting days

\section{Nickel}

The quantity of $\mathrm{Ni}$ accumulated by $P$. fruticose is presented on Fig. 6 A significant ( $\mathrm{p}$ $<0.05)$ quantity of $\mathrm{Ni}(56.89 \pm 16.18 \mathrm{mg} / \mathrm{kg})$ in the root on 180 harvesting day was observed. Other high accumulations were observed on the stem and leaf on 180 experimental days with concentrations $43.28 \pm 6.71$ and $39.55 \pm 11.15 \mathrm{mg} / \mathrm{kg}$ respectively. All the accumulation in the $P$. fruticose organs was observed to be higher compared to the control plant and soil samples. Moreover, it was observed that the accumulation of $\mathrm{Ni}$ in plant parts was higher on 120 and 180 days compared to 240 and 300 days. In a similar study by Roccotiello 32 in a Ni phytoremediation potential of Mediterranean Alyssoides utriculata (L.) Medik, the finding showed that, concentration of
$\mathrm{Ni}$ accumulated in the leaf of the plant was greater than $1000 \mu \mathrm{g} / \mathrm{g}$ and this classified the plant as a $\mathrm{Ni}$ hyper accumulator plant ${ }^{32}$. A high concentration of $\mathrm{Ni}$ was observed in the root of $P$. fruticose at all the harvesting days, followed by the stem on 60 and 120 days. Accumulation of $\mathrm{Ni}$ decreases in the trend root $>$ stem > leaf on 60 and 120 experimental days and root $>$ leaf $>$ stem on 180 and 240 harvesting days. In contrast to this experiment, a higher concentration of $\mathrm{Ni}$ was found on the stem and leaf of Vetiveria zizanioides more than the root of the plant ${ }^{33}$. Uptake of $\mathrm{Ni}$ in the root, stem and leaf of $P$. fruticose was observed to be inconsistent in the trend, instead the accumulation followed the trend root $>$ stem $>$ leaf for 60 and 120 days, while root $>$ stem < leaf for 180 and 240 days.

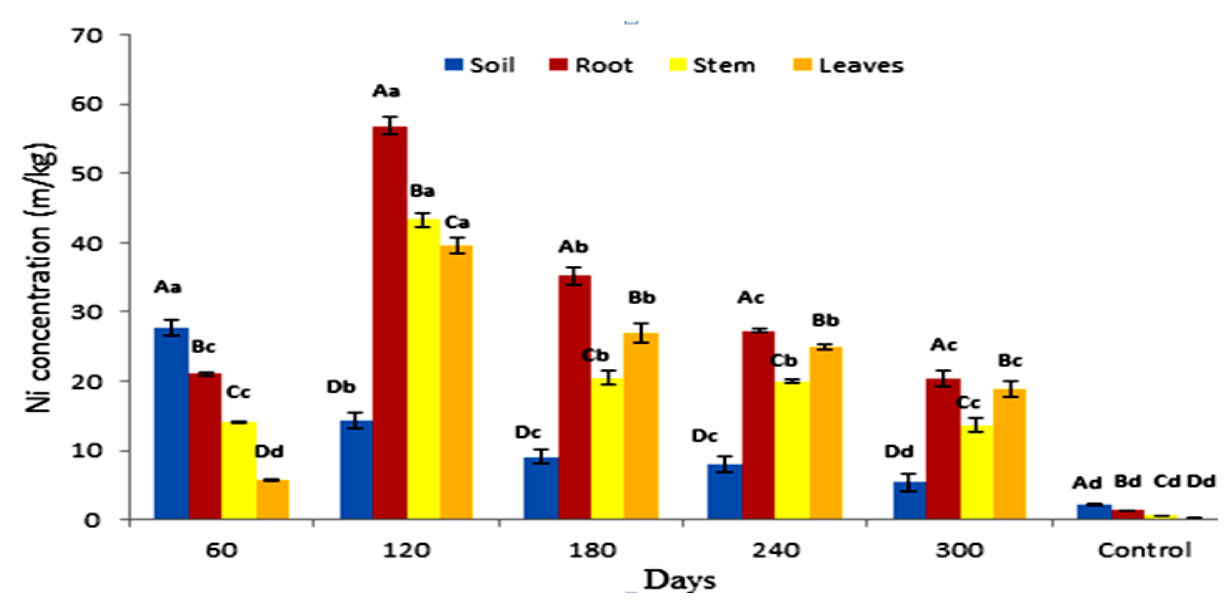

Fig. 6. Accumulation of $\mathrm{Ni}$ concentration in soil and $P$. fruticose root, stem and leaf on all the harvesting days

Furthermore, results indicated a relatively less $\mathrm{Ni}$ ranslocation from root to stem and stem to leaf on 60 and 120 days. P. fruticose was observed to show a high potential to uptake and accumulation of 
$\mathrm{Ni}$ in the root on all the experimental days. Salvinia cucullata was found to accumulate $\mathrm{Ni}$ in the leaf more than root in the first 3 treatments applied. It was observed that as the effluent concentration increases the accumulation of $\mathrm{Ni}$ in the leaf decreases while at the extreme concentration of the treatment, $S$. cucullata accumulated more $\mathrm{Ni}$ in the root $34.9 \pm 0.93$ $\mathrm{mg} / \mathrm{kg} 27$. Most plants are able to accumulate $\mathrm{Ni}$ into the root and translocate it to the aboveground tissue by passive and active processes. A high concentration of $\mathrm{Ni}$ was observed in the root more than the stem and leaf when plants are grown on soil contaminated with high quantity of $\mathrm{Ni}$. It was noticed also that excess $\mathrm{Ni}$ in the soil may affect the biosynthesis of metalloenzymes by making some important metals iinadequate and also decreases the absorption of Fe by the plant ${ }^{34}$.

\section{Lead}

The quantity of $\mathrm{Pb}$ accumulated by $P$. fruticose is presented on Fig. 7 and a significant $(p<0.05)$ concentrations were observed to increase from 60 to 240 harvesting days and also from root to leaf except for the 60 and 300 experimental days. Furthermore, the accumulation of $\mathrm{Pb}$ by $P$. fruticose parts was several times higher than the concentration in the control plant parts. A significant $(\mathrm{p}<0.05)$ amount of $\mathrm{Pb}$ accumulated by $P$. fruticose was found in the leaf $(96.37 \pm 3.89 \mathrm{mg} / \mathrm{kg})$ and least $\mathrm{Pb}$ accumulation was also found in the leaf $(1.22 \pm 0.17 \mathrm{mg} / \mathrm{kg})$ on 240 and 60 harvesting days, respectively. In the experiment conducted on phytoremediation potential for $\mathrm{Pb}, \mathrm{Zn}$ and $\mathrm{Cu}$ using indigenous plants, a range of $\mathrm{Pb}$ accumulation was presented as 3.44 to $364.47 \mathrm{mg} / \mathrm{kg}$ dry weight in the tissues of the plants ${ }^{35}$. This study is in accordance with the finding reported by Mkumbo et al.,35. The low accumulation of $\mathrm{Pb}$ found in this experiment was in accordance with finding reported by Knapp et al., ${ }^{36}$, in the $\mathrm{Pb}$ uptake by carrots, tomatoes and amaranth with concentrations ranged from 0.3 to 1.9 $\mathrm{mg} / \mathrm{kg}^{36}$. Normally, the plants that accumulated low $\mathrm{Pb}$ concentration they do so may be as a result of the toxicity of $\mathrm{Pb}$. Photosynthetic processes, anti-oxidant enzymes and synthesis of chlorophyll can be affected by $\mathrm{Pb}$ toxicity ${ }^{37}$. Olowu et al., ${ }^{38}$ stated that the uptake and high accumulation of $\mathrm{Pb}$ at the plant roots may not be translocated to shoots, fruits and seed due to its low solubility and strong barrie ${ }^{38}$. Experiment on $\mathrm{Pb}$ uptake in $P$. fruticose shows that leaf has accumulated higher amount of $\mathrm{Pb}$ compared to stem and root. Increasing quantity of $\mathrm{Pb}$ accumulation in the leaf was found to be $32.85,61.71$ and 96.37 $\mathrm{mg} / \mathrm{kg}$ on 120,180 and 240 days, respectively. It was observed that, the amount of $\mathrm{Pb}$ accumulated by the tissues of $P$. fruticose increases from root to stem to leaf. Therefore, the uptake followed the trend root < stem < leaf on all the harvesting days except on the first 60 days. The trend of $\mathrm{Pb}$ transfer indicated that $\mathrm{Pb}$ was efficiently transferred from the soil to root, root to stem and stem to leaf. The accumulation of $\mathrm{Pb}$ into plant organs is an indication of the quantity of $\mathrm{Pb}$ contained in the soil or environment. It was observed that small quantity of $\mathrm{Pb}$ are soluble and bioavailable for absorption into plants root from the soil, which could be due to a strong binding between $\mathrm{Pb} /$ organic materials and $\mathrm{Pb} /$ colloidal materials ${ }^{39}$. The potential of plant and cultivars species differs in $\mathrm{Pb}$ accumulation, which also depends on $\mathrm{Pb}$ availability in the soil and various soil properties ${ }^{39}$.

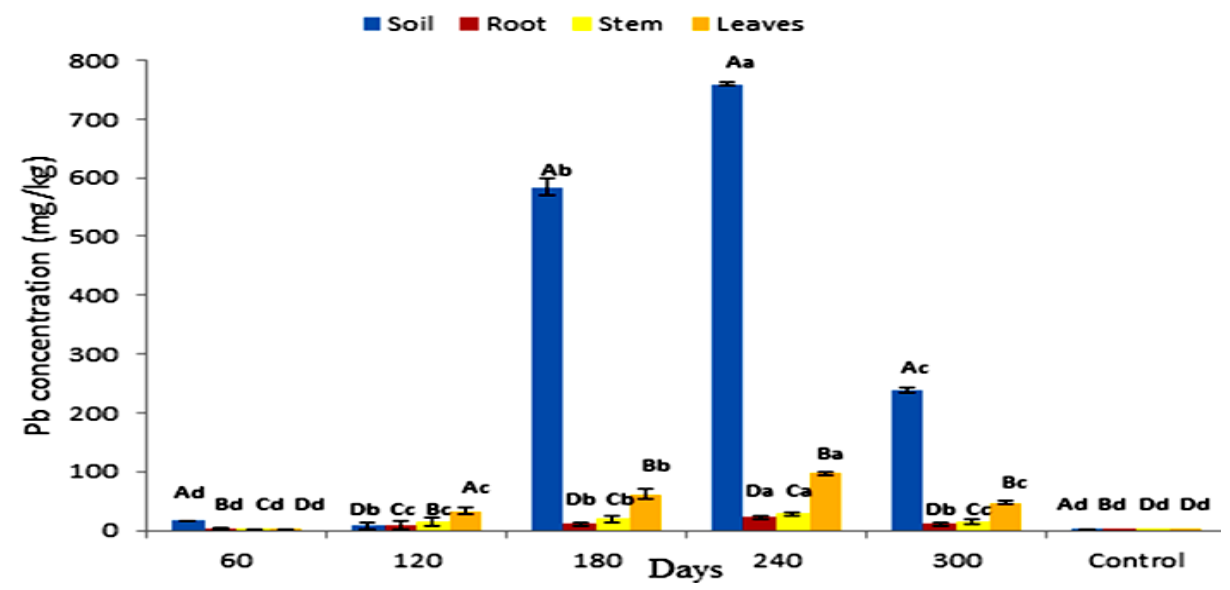

Fig. 7. Accumulation of $\mathrm{Pb}$ concentration in soil and $P$. fruticose root, stem and leaf on all the harvesting days 


\section{Zinc}

Accumulation of $\mathrm{Zn}$ by $P$. fruticose root, stem and leaf is presented on figure 8 . A significant $(p<0.05)$ concentration of $\mathrm{Zn}$ was observed to be higher in the root of the plant at all the harvesting days compared to other plant parts with concentrations $14.56,58.58,193.34,49.25$ and $73.27 \mathrm{mg} / \mathrm{kg}$ on $60,120,180,240$ and 300 days respectively. The quantity of $\mathrm{Zn}$ in $P$. fruticose part was found higher compared to $\mathrm{Zn}$ concentration in control plant part on all harvesting days. A significant $(p<0.05)$ amount was found in the root on 120 day with concentration $193.34 \pm 36.07 \mathrm{mg} / \mathrm{kg}$. It was observed that, translocation of $\mathrm{Zn}$ from root to shoot of the plant decreases in the trend root $>$ stem $>$ leaf on all harvesting days. Other higher amount of $\mathrm{Zn}$ in stem and leaf of the plant were found on 180 and 120 harvesting days with a concentration $29.75 \pm$ 4.40 and $27.88 \pm 2.21 \mathrm{mg} / \mathrm{kg}$ respectively. This study agreed with the similar experiment carried out on $\mathrm{Zn}$ uptake using different plant species by Subhashini et $a l .{ }^{40}$, they reported that Acalypha indica and Ruellia tuberosa accumulated $\mathrm{Zn}$ in the tissues following the trend root $>$ stem $>$ leaf.

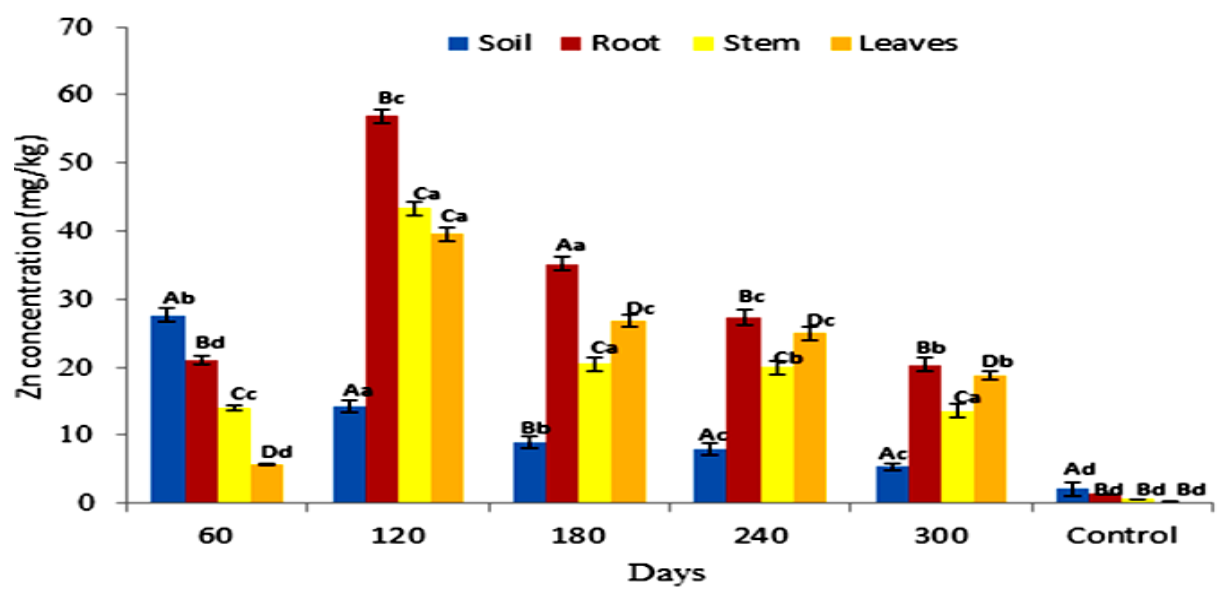

Fig. 8. Accumulation of $\mathrm{Zn}$ concentration in soil and $P$. fruticose root, stem and leaf on all the harvesting days

A. indica was able to accumulate $\mathrm{Zn} 131.36$, 53.93 and $49.92 \mathrm{mg} / \mathrm{kg}$ and $R$. tuberosa 49.99, 44. 86 and $32.77 \mathrm{mg} / \mathrm{kg}$ both for the root, stem and leaf respectively on 60 experimental day ${ }^{40}$. In contrary to this experiment, Limnobium laevigatum was found to accumulate a significant concentration of $\mathrm{Zn}$ in the leaf. They also reported that there were no significant changes in the accumulation of $\mathrm{Zn}$ from the root and leaf over a period of time ${ }^{41}$. High $\mathrm{Zn}$ concentration $(193.34 \mathrm{mg} / \mathrm{kg})$ was found in the root on 180 days followed by $(58.58 \mathrm{mg} / \mathrm{kg})$ on 120 days and $(49.25 \mathrm{mg} /$ $\mathrm{kg}$ ) on 240 days. Zinc is an essential metal to plant in which a normal plant can have an average value of $\mathrm{Zn} 66.0 \mathrm{mg} / \mathrm{kg}$ in the stem or leaf ${ }^{9}$. In this study the concentration of $\mathrm{Zn}$ in the stem and leaf were below the normal plant $\mathrm{Zn}$ concentration. However, the uptake of $\mathrm{Zn}$ from root to stem and stem to leaf were found to be decreasing on all the harvesting days. Consequently, Zn concentration was found higher in the root than the stem and leaf. Moreover, transfer of $\mathrm{Zn}$ from root to stem and leaf was lower compared to transfer from soil to the root of the plant. It was reported that, when $\mathrm{Zn}$ is effective it can move and transfer from plant root to shoot and becomes accountable for lowering the amount of important plants nutrients and hinder some biochemical reaction ${ }^{42}$. It was also reported that in order to translocate $Z n$ from root to the shoot, Zn has to move through many different tissues before the xylem of the plant was reached ${ }^{43}$. But in this experiment $\mathrm{Zn}$ was not transferred to aboveground tissue so easily. Accordingly, $\mathrm{Zn}$ is capable of moving and it is accessible biologically, consequently, its high amount in the soil and plant can enter into the food chain ${ }^{9}$.

\section{Bio-concentration Factor (BCF), Translocation Factor (TF) and Extraction Coefficient (EC) \\ $\mathrm{BCF}$, TF and EC values obtained are} presented in Fig. 9, 10 and 11 respectively. The threshold value for BCF > 1 was obtained by many heavy metals on different harvesting days. The high BCF value was achieved by Ni with 9.77, 9.09 and 9.05 values for 120,180 and 240 harvesting days respectively. Other high values were achieved by $\mathrm{Cr}$ 
(5.08), $\mathrm{Co}$ (7.55) and $\mathrm{Pb}$ (7.09) on 120 harvesting day. It was detected that $\mathrm{Cr}$ and $\mathrm{Ni}$ achieved a BCF value of $>1$ in the entire harvesting days of $60,120,180$ and 240, while Fe was not able to achieve the BCF threshold value. Minimum value was observed in $\mathrm{Fe}$ on 60 harvesting day with $\mathrm{BCF}$ value of 0.002 . High and low BCF values of 5.57 and 0.02 were observed in Sphaeranthus africanus (L.) and Celosia triggna L. respectively ${ }^{35}$ and is similar to this experiment. The TF threshold of $>1$ was observed in $\mathrm{Co}, \mathrm{Cr}, \mathrm{Ni}, \mathrm{Mn}$, $\mathrm{Zn}$, Fe and $\mathrm{Pb}$ heavy metals at different experimental days except $\mathrm{Cu}$ which did not achieve TF value $>1$ on all the experimental days. Chromium $(\mathrm{Cr})$ was observed to achieved TF threshold of $>1$ on all the harvesting days. It was observed that $\mathrm{Pb}$ has the highest TF value on 120, 180 and 240 harvesting days compared to other metals. Chromium failed to be efficiently translocated to the shoot when compared to other heavy metals, and Fe was poorly translocated. The highest TF values were observed at different experimental days, $\mathrm{Cr}(\mathrm{TF}=2.73), \mathrm{Pb}$ $(\mathrm{TF}=7.37), \mathrm{Pb}(\mathrm{TF}=5.7)$ and $\mathrm{Pb}(\mathrm{TF}=5.29)$. Therefore, these results indicated that $P$. fruticose is an excluder species to $\mathrm{Cu}$ and $\mathrm{Fe}$ while it is an accumulator to $\mathrm{Co}, \mathrm{Cr}, \mathrm{Ni}, \mathrm{Mn}, \mathrm{Pb}$ and zinc.

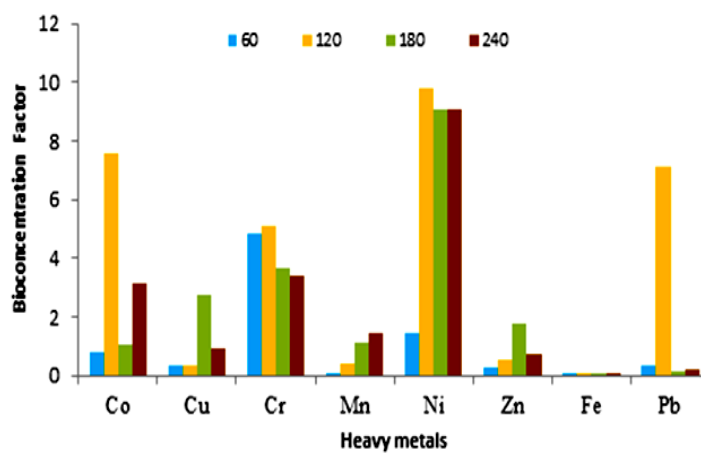

Fig. 9. Comparative BCF of $\mathrm{Co}, \mathrm{Cu}, \mathrm{Cr}, \mathrm{Mn}, \mathrm{Ni}, \mathrm{Zn}, \mathrm{Fe}$ and $\mathrm{Pb}$ in $P$. fruticose at different harvesting time

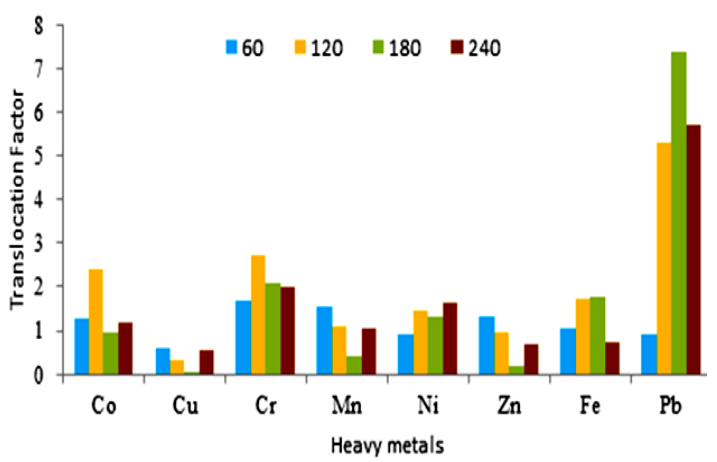

Fig. 10. Comparative TF of $\mathrm{Co}, \mathrm{Cu}, \mathrm{Cr}, \mathrm{Mn}, \mathrm{Ni}, \mathrm{Zn}, \mathrm{Fe}$ and $\mathrm{Pb}$ in $P$. fruticose at different harvesting days

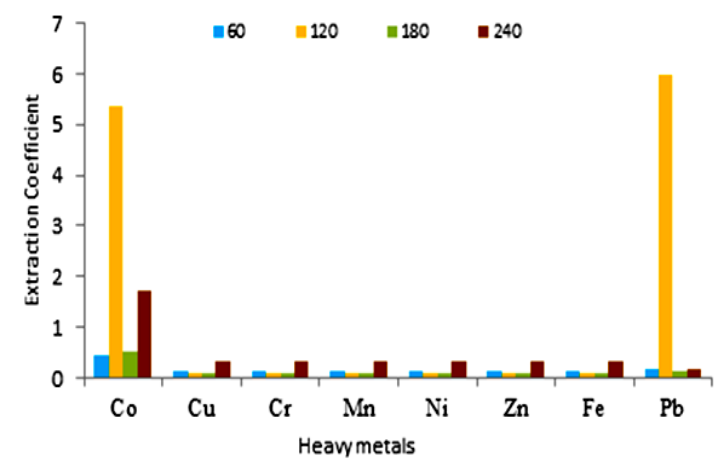

Fig. 11. Comparative $\mathrm{EC}$ of $\mathrm{Co}, \mathrm{Cu}, \mathrm{Cr}, \mathrm{Mn}, \mathrm{Ni}, \mathrm{Zn}, \mathrm{Fe}$ and $\mathrm{Pb}$ in $P$. fruticose at different harvesting days

The EC threshold value of $>1$ was obtained by $\mathrm{Ni}$ and $\mathrm{Cr}$ on all the harvesting days. Maximum EC was achieved by $\mathrm{Pb}$ on 120 days with value 5.96 followed by $\mathrm{Ni}$ on 120,180 and 240 harvesting days with values 5.79, 5.21 and 5.63 respectively. Cobalt (Co) also obtained a maximum value of 5.34 on 120 experimental days, while the remaining metal shows $E C<1$ throughout the harvesting days.

\section{CONCLUSION}

Soils that are polluted with heavy metals or metalloid are not easy to be remediated. The practice of soil clean-up is very expensive; therefore a low cost technology is needed for rectifying contaminated soil. A recent technology called phytoremediation is cost effective and affordable for reducing or removing heavy metals and metalloids from contaminated soil. In this study, growth, survival ability, accumulation of heavy metals in the roots, stem and leaf, the relationship between the metal concentration in the soil, root and shoots were the factors of concern in conducting the experiment. According to the results obtained, $P$. fruticose was a good accumulator for most of heavy metals because the concentration ratio of the heavy metals in the plant to that in the soil (BCF) was $>1$. P. fruticose plant has the potential to be used in the phytoextraction of some heavy metals with BCF and TF > 1. Furthermore, it has the ability to be used in phytostabilization for the heavy metals with $\mathrm{BCF}$ and TF values $<1$. The results obtained can be considered as a practical demonstration for the use of $P$. fruticose in the phytoremediation of several heavy metal contaminated soils and it's the novelty of the experiment. 
All authors contributed in carrying out the experiments and writing of the manuscript. All authors read and approved the final manuscript.

\section{ACKNOWLEDGMENT}

The authors would like to express gratitude to the Faculty of Resource Science and Technology,
Universiti, Malaysia, Sarawak, and the study leave granted to Naseer Inuwa Durumin lya by Federal University Dutse, Jigawa State Nigeria for his Ph.D is also acknowledged.

\section{Conflict of interest}

We declare that we have no conflict of interest.

\section{REFERENCES}

1. Chang, F.C.; Ko, C.H.; Tsai, M.J.; Wang, Y.N.; Chung, C,Y. Ecotox., 2014, 23(10), 1969 - 1978.

2. Ullah, A.; Henga, S.; Munis, M. S. H.; Fahad, S.; Yanga, X. Environ and Exp Bot., 2015, 17, 28-40.

3. Pandey, V. C. Ecotox. Environ. Safe., 2012, 82, 8-12. 4. Iqbal, M. P. Pak J Pharm Sci., 2012, 25, 289-294.

5. Wuana, R. A.; Okieimen, F. E. Ecol., 2011, 1-20.

6. Beskoski, V. P.; Gojgic-Cvijovic, G.; Milic, J.; Ilic, M.; Miletic, S.; Solevic, T.;Vrvic, M. M. Chemos., 2011, 83, $34-40$.

7. Sawidis, T.; Krystallidis, P.; Veros, D.; Chettri, M. Bio Trace Element Resour., 2012, 148(3), 396-408.

8. Singh, R.; Singh, D. P.; Kumar, N.; Bhargava, S. K.; Barman, S. C. J Environ Bio., 2010, 31, 421- 430.

9. Durumin Iya, N. I.; Assim, Z.B.; Ipor, I.I.; Omolayo, A.O.; Umaru, I.J.; Jume, B.H. Indones. J. Chem., 2018, 18(3), 503 - 513.

10. Karam, D.; Rajoo, K.; Ismail, A.; Muharam, F.M. Am. J. Agric. Environ. Sci., 2016, 16(8), 1504-1514.

11. Kaewtubtim, P.; Meeinkuirt, W.; Seepom, S.; Pichtel, J. Appl. Ecol. Environ. Res., 2016, 14(1), 367-382.

12. Lago-Vila, M.; Arenas-Lago, D.; RodríguezSeijo, A.; Andrade Couce, M. L.; Vega, F. A. Solid Earth., 2015, 6, 323-335.

13. Khan, Z. I.; Ahmad, K.; Ashraf, M.; Parveen, R.; Mustafa, I.; Khan, A.; Bibi, Z.; Akram, N. A. Pak. J. Bot., 2015, 47(1), 217-224.

14. Yamaguchi, T.; Tomioka, R.; Takenaka. Int. J. Mol. Sci., 2015, 16, 21378-21391.

15. Kabata-Pendias, A. Trace Elements in Soils and Plants., 2011, 227-251.

16. Ali, H.; Khan, E.; Sajad, M. A. Chemos., 2013, 91, 869-881.

17. Lange, B.,; van der Ent, A.; Baker, A. J. M.; Echevarria, G.; Mahy, G.; Malaisse, F.; Meerts, P.; Pourret, O.; Verbruggen, N.; Faucon, M. P.
New Phytol., 2016, 213, 537 - 551.

18. Adki, V. S.; Jadhav, J. P.; Bapat, V. A. Environ. Sci .Pollut. Res., 2013, 20, 1173-1180.

19. Rafati, M.; Khorasani, N.; Moattar, F.; Shirvany, A.; Moraghebi, F.; Hosseinzadeh, S. Intl. J. Environ. Res., 2011, 5, 961-970.

20. Tayim, A.; Alyazouri, A.; Jewsbury, R. A.; Tayim, H.; Humphreys, P. N.; Al-Sayah, M. H. Toxicol. Environ. Chem., 2014, 95(8), 1029 - 486.

21. Ali, H.; Naseer, M.; Sajad, M. A. Int . J. Environ. Sci., 2012, 2, 1459-1469.

22. Emamverdian, A.; Ding, Y.; Mokhberdoran, F.; Xie, Y. The Sci. World J., 2015, 1-18.

23. Feigl, G.; Kumar, D.; Lehotai, N.; Tugyi, N.; Molnar, A.; Ordog, A.; Szepesi, A., Gemes, K.; Laskay, G.; Erdei, L.; Kolbert, Z. Ecotoxicol. Environ. Safe., 2013, 94, 179-189.

24. Rahman, M. M.; Tan, P. J.; Faruq, G.; Sofian, A. M.; Rosli, H.; Boyce, A. N. Int. J. Agri.c Bio., 2013, 15, 903 - 908.

25. Leura-Vicencio, A.; Alonso-Castro, A. J.; Carranza-Alvarez, C.; Loredo-Portales, R.; Torre, M. C. A.; Cruz, R.F. G. Bull. Environ. Cont. Toxicol., 2013, 90, 650-653.

26. Lorestani, B.; Cheraghi, M.;Yousefi, N. Arch. Bio. Sci., 2011, 63(3), $739-745$.

27. Das, S.; Mazumdar, K. Chemos., 2016, 163, 62-72.

28. Tangahu, B.V.; Abdullah, S.R.; Basri, H.; Idris, M.; Anuar, N.; Mukhlisin, M. Int. J. Chem. Eng., 2011, 1-31.

29. Bhat, I. U.; Mauris, E. N.; Khanam, Z. Int. J. Phytorem., 2016, 18(9), 918-23.

30. Xie, W.; Huang, Q.; Li, G.; Rensing, C.; Zhu, Y. Int. J. Phytorem., 2013, 15, 385-397.

31. Satpathy, D.; Reddy, M. V. Appl. Ecol. Environ. Res., 2013, 11(4), $661-679$. 
32. Roccotiello, E.; Serrano, H. C.; Giorgio, M.; Branquinho, M. C. Chemos., 2015, 119, 1372 - 1378.

33. Gunwal, I.; ingh, L.; Mago, P. Int. J. Sci. Res. Pub., 2014, 4(10), 1-7.

34. Nie, J.; Pan, Y.; Shi, J.; Guo, Y.; Yan, Z.; Duan, X.; Xu, M. Int. J. Environ. Res. Pub. Health., 2015, 12, 15075-15087.

35. Mkumbo, S.; Mwegoha, W.; Renman, G. Int. J. Environ. Sci., 2012, 2(4), 2425-2434.

36. Knapp, L.; Sangster, J.; Bartelt-hunt, S. L. Int. J. Serv. Earn. Eng., 2013, 8(2), 1-7.

37. Nematian, M.A.; Kazemeini, F. Intl. J. Agric Crop Sci., 2013, 5(4), 426-432.

38. Olowu, A. R.; Adewuyi, O. G.; Onipede, J. O.;
Oladipo, A.; Lawal, A.O.; Owolabi, M.; Sunday, M. O. Am J Chem., 2015, 5(1), 40 - 48.

39. Amin, H.; Arain, B.A.; Jahangir, T.M.; Abbasi, M.S.; Amin, F. Geology, Ecology, and Landscapes., 2018, 2(1), 51-60.

40. Subhashini, V.; Swamy, A.V.V.S.; Krishna, R. H. World. J. Environ. Eng., 2013, 2, 27-33.

41. Aran, D.S.; Harguinteguy, C.A.; FernandezCirelli, A.; Pignata, M.L. Environ. Sci. Pollut. Res. Int., 2017, 24(22), 18295-18308.

42. Sheel, D. R.; Anand, M.; Nisha, K. Intl. J. Sci. Res., 2013, 4(7), $1238-1241$.

43. Gupta, N.; Ram, H.; Kumar, B. Rev. Environ. Sci. Biotech., 2016, 15, 89-109. 